\title{
SIMULATION-BASED OPTIMIZATION FOR AN ORIGAMI-SHAPED CANOPY
}

\section{OTIMIZAÇÃO BASEADA EM SIMULAÇÃO PARA UMA COBERTURA INSPIRADA EM ORIGAMI}

\author{
Caio de Carvalho Lucarelli ${ }^{1}$ \\ Universidade Federal de Viçosa, Viçosa, MG, Brasil, caio.lucarelli@ufv.br \\ Joyce Correna Carlo ${ }^{2}$ \\ Universidade Federal de Viçosa, Viçosa, MG, Brasil, joycecarlo@ufv.br \\ Andressa Carmo Pena Martinez ${ }^{3}$ \\ Universidade Federal de Viçosa, Viçosa, MG, Brasil, andressamartinez@ufv.br
}

\begin{abstract}
This study perceives the developing process of Simulation-based Optimization (SBO), using Octopus ${ }^{\circledR}$ for Grasshopper $^{\circledR}$. This investigation aimed to optimize an Origami-inspired canopy designed to admit solar radiation and daylight in transitional spaces. As optimization objectives, we employed the maximization of Physiological Equivalent Temperature (PET) and Useful Daylight Illuminance (UDI). The method consists of shape optimization, considering the exclusion of non-robust parameters according to factorial analysis. The second step regards computational simulations for the admission of solar radiation and daylight performance within transitional spaces, followed by a comparative evaluation of the best solutions generated through the simulation process. We ran the simulations using Ladybug ${ }^{\circledast}$ and Honeybee ${ }^{\circledast}$ plugins. We simulated the canopy in three different transitional zones, which resulted in distinct shapes and performances. We adopted transitional spaces because they are neither indoor nor outdoor, and comfort standards are rarely evaluated. As the main results, the optimization generated maximum comfort of $93.75 \%$ for PET Percentage Time Comfortable and $93.8 \%$ for UDI for naturally conditioned spaces. These results denote that users are in thermal comfort for $93.75 \%$ of the time. For $93.8 \%$ of the evaluated time, illuminance levels are between 100 and $2000 \mathrm{~lx}$, and therefore in agreement with the recommended levels.
\end{abstract}

Keywords: Multicriteria Design Optimization. Transitional Spaces. Octopus. Physiological Equivalent Temperature. Useful Daylight Illuminance.

\begin{abstract}
Resumo
Este estudo compreende o processo de desenvolvimento de uma Otimização baseada em Simulação (OBS), usando o plugin Octopus ${ }^{\circledR}$ para Grasshopper ${ }^{\circledR}$. Esta investigação teve como objetivo otimizar uma cobertura inspirada em Origami, projetada para admitir radiação solar e luz natural em ambientes de transição. Como objetivos da otimização, empregamos a maximização da Temperatura Fisiológica Equivalente (PET) e da lluminância Natural Útil (UDI). O método consiste na otimização da geometria, considerando a exclusão de parâmetros não robustos. O segundo passo refere-se a simulações computacionais para admissão de radiação solar e desempenho da luz natural, seguido de uma avaliação comparativa das melhores soluções geradas. Realizamos as simulações usando os plugins Ladybug ${ }^{\circledast}$ e Honeybee ${ }^{\circledast}$. Simulamos a cobertura em três zonas de transição diferentes, o que resultou em formas $e$ desempenhos distintos. Adotamos espaços de transição por não se classificarem como internos ou externos, com padrões de conforto raramente avaliados. Como principais resultados, a otimização gerou níveis máximos de conforto de 93,75\% para o PET Percentual de Conforto e 93,8\% para o UDI em espaços naturalmente condicionados. Esses resultados indicam que os usuários estão em conforto térmico por 93,75\% do tempo. Para 93,8\% do tempo, os níveis de iluminação estão entre 100 e 2000 lx.
\end{abstract}

Palavras-chave: Otimização multicritério. Espaços de Transição. Octopus. Temperatura Fisiológica Equivalente. Iluminância Natural Útil.

How to cite this article:

LUCARELLI, C. DE C.; CARLO, J. C.; MARTINEZ, A. C. P. Otimização baseada em simulação para uma cobertura inspirada em origami. PARC Pesquisa em Arquitetura e Construção, v. 11, p. e020013, 4 ago. 2020.

DOI:https://doi.org/10.20396/parc.v11i0.8658250 


\section{Introduction}

Research on thermal comfort often concentrates on indoors (CHUN; KWOK; TAMURA, 2004). Notwithstanding, in the last two decades, there has been substantial research on outdoor thermal comfort (PENG; FENG; TIMMERMANS, 2019). In architecture, transitional areas between indoors and outdoors, deserve investigation due to their potential to provide a comfortable environment at certain times of the year and thus save energy.

Building simulations have been steadily established as a part of computational applications for the design process over the last two decades. The primary objective of their use is to run a performance analysis that informs, for instance, more efficient design alternatives that satisfy multiple criteria (YIGIT; OZORHON, 2018). They help speed up the design process and increase building efficiency, which leads to more optimal designs.

Along with the simulation tools, Simulation-based Optimization (SBO) has been increasingly employed to manage complex engineering systems, achieving optimal solutions with less time and labor (NGUYEN; REITER; RIGO, 2014). SBO investigations mostly regard the selection of construction types and materials as optimization parameters. Fewer studies consider basic shape variables such as window-to-wall ratio and orientation. Concerning optimization objectives, researches are mainly focused on energy performance, thermal comfort, and environmental impacts (FANG, 2017).

Acknowledging that the building envelope determines daylight admittance and thermal exchange with the outdoors, the importance of the built environment in the total energy consumption should be highlighted. In this scenario, solar shading devices can improve energy performance and thermal comfort (CARTANA, 2018; CHO; YOO; KIM, 2014).

Besides, we observe the impact of the advancement of digital tools and the changes in design processes, since, according to Oxman (2006), increased production processes have been observed in contemporary architecture. Furthermore, the appropriation and adaptation of digital manufacturing processes have resulted in technological innovations that allow greater design freedom and customization of building components (CARTANA, 2018).

This paper strives to probe and perform an SBO for an Origami-inspired canopy in transitional spaces. The parameterization of the Origami-shaped canopy and the selection of optimization parameters and objectives were elaborated in previous work (LUCARELLI; CARLO, 2020), using Rhino3D+Grasshopper ${ }^{\oplus}$ suite.

As optimization objectives, we employed the maximization of Percentage Comfort for Physiological Equivalent Temperature (PET) and maximization of average Useful Daylight Illuminance (UDI).

\section{Literature review}

Energy consumption and building performance

Increased energy consumption resulted in a shortage of energy resources and environmental deterioration (ZHOU et al., 2019). The building sector is one of the world's largest energy consumers, using $45 \%$ of the total primary energy requirement and producing $30 \%$ of carbon emissions worldwide (LOPES; CÓSTOLA; LABAKI, 2017). 
In Brazil, the building sector spends around $50.7 \%$ of the national total energy demand, with commercial buildings accounting for $34 \%$ of this amount (PEREIRA et al., 2017).

According to Yu and Su (2015), it is important to address the physical characteristics of the building to reduce energy expenditure and improve its performance. This also promotes a better understanding of how buildings perform since they comprise nonspatial variables that affect the final design (KO, 2013).

Energy performance depends on decisions made in different design stages, essentially the early ones. The building design is a complex process in which specialists from different fields contribute to the decision-making to meet all performance criteria (YIGIT; OZORHON, 2018). The use of shading devices, for instance, usually helps reducing solar heat gains but also leads to a reduction of natural daylight and hence, an increase in artificial lighting and energy consumption. Therefore, finding effective alternatives that meet multiple standards is challenging.

For instance, Kirimtat et al. (2019) developed a Multicriteria Design Optimization (MCDO) for an amorphous shading device, aiming to maximize illuminance levels, using dynamic measures while minimizing Total Energy Consumption (TEC). As a result, they managed to keep average UDI between $52.03 \%$ and $57.13 \%$, while reducing TEC.

Cartana (2018) has also incorporated radiation and daylight SBO to the process of designing a parametric shading device. He minimized the beam radiation and applied a series of dynamic measures, such as Useful Daylight Illuminance (UDI). Grobman, Capeluto, and Austern (2017) also investigated louvers to ensure proper illuminance and radiance levels indoors and reached $33.68 \%$ better UDI than unshaded window solutions.

\section{Building Performance Simulation (BPS)}

In recent decades, applications of Building Performance Simulation (BPS) for handling complex engineering systems have emerged as a promising method (GARBER, 2009).

Even though Brazil has sustainable construction manuals and guidelines from certification bodies, such material addresses slender buildings with lengthy façades towards north and south and windowless façades for the other orientations. These practical rules cannot be applied to different building geometries (CAMPOS, 2017). Thus, it is essential to use BPS when working with the performance-based design process.

Wong (2017) presented an extensive review of BPS tools for daylighting. The most frequently used programs are Radiance ${ }^{\circledR}$, Ecotect $^{\circledast}$, DOE $^{\circledast}$, Daysim $^{\circledast}$, and EnergyPlusTM. The two most commonly used calculation methods for daylight simulation are raytracing, which is a view-dependent algorithm utilized by Radiance ${ }^{\circledR}$, and radiosity, which is a scene-dependent algorithm used in $\operatorname{Relux}^{\circledast}$ (YU; SU, 2015).

Radiance ${ }^{\circledast}$ is the most current daylight simulation tool that uses backward ray-tracing (YU; SU, 2015). It is extensively applied in daylight-related investigations and validated by researchers such as Ochoa, Aries, and Hensen (2012).

For BPS, EnergyPlusTM is one of the most accessible software systems. It is an advanced whole-building energy simulation engine that can be used to model energy consumption in buildings. Simulation results are highly accurate, based on ASHRAE Standards, and validated by different researchers (ANDJELKOVIC; MUJAN; DAKIC, 2016; MATEUS; PINTO; GRAÇA, 2014).

Ladybug $^{\oplus}$ and Honeybee ${ }^{\circledast}$ are energy and daylight modelling plugins for Grasshopper ${ }^{\circledast}$. Ladybug $^{\circledast}$ imports standard EnergyPlusTM Weather files (.epw) into Grasshopper ${ }^{\circledast}$, 
providing a variety of interactive graphics to support the decision-making process. It also allows users to work with validated energy and daylight engines, such as EnergyPlusTM and Radiance ${ }^{\circledast}$, exempting the need for further validation (ROUDSARI; PAK, 2013). Honeybee ${ }^{\circledast}$ runs analysis for advanced building masses. It also automates the process of intersecting the masses and finding surfaces, so the user needs only to provide floor heights and the internal activities for each zone.

In BPS, the modeling process begins in Grasshopper ${ }^{\circledR}$ with parametric design variables and building geometry. Ladybug ${ }^{\circledR}$ and Honeybee ${ }^{\circledR}$ provide the modules for daylight and energy simulation. In the daylight modeling process, the building zones are connected to the Radiance ${ }^{\circledast}$ material component to insert a reflectance. Then, the materials are connected to the daylight simulation component and the daylight sensor placement. The Radiance ${ }^{\circledast}$ daylight simulation component generates an output that feedbacks Ladybug $^{\circledR}$. After the simulation, Ladybug ${ }^{\circledR}$ imports the .epw back to Grasshopper ${ }^{\circledR}$ and renders the annual schedule (FANG, 2017).

\section{Parametric simulation and parametric modeling}

Along with comfort and energy efficiency matters, we can observe that the use of digital tools is redefining architecture (CARTANA, 2018). Architects are exploiting these tools and creating new possibilities in design, fabrication, and construction.

In building science, designers use dynamic simulations to analyze thermal and energy efficiency and achieve specific goals. The most traditional approach to dynamic simulation is the parametric simulation. Initially, it consisted of analogically changing one simulation input variable and keeping all others constant, which allowed estimating each variable's effect on building performance. However, this process omitted the identification of optimal design solutions since it did not acknowledge the intercommunication between variables (KOLAREVIC; MALKAWI, 2006).

In contrast, parametric modelling is a design tool for the creative process. The variability of solutions presented by this tool helps to evaluate several alternatives before choosing a definitive solution. Therefore, BPS can be integrated with parametric modelling as an essential decision-aiding tool (KOLAREVIC; MALKAWI, 2006).

The term parametric originates from mathematics and refers to using specific variables to manipulate the equation results (FRAZER, 2016). Parametric modelling, different from parametric simulation, refers to the automated parameter-based generation of any design element, which means managing the generation and altering any component with specific algorithm-generated rule-sets (ELTAWEEL; SU, 2017).

Although relatively new in Brazil, the implementation of shape parameters in building's geometric optimization has been investigated in many publications, especially with a numerical approach using Multicriteria Design Optimization (MCDO) (CARTANA, 2018; FANG, 2017).

In architecture, digital shape modeling has been called parameterization. Its resignification consists of creating a rule-based description for shapes, which allows the easy modification of parameters, generating multiple solutions that can be analyzed to meet different criteria. These parameters can vary from geometric determinations to solar gain and structural rigidity, allowing design optimization and more intelligent structures (CAMPOS, 2017). This computation also allows reducing the time spent in the design process and providing more precise results. 


\section{Simulation-Based Optimization (SBO)}

Designers can achieve building thermal performance through two approaches: trial-anderror or optimization (GOSSARD; LARTIGUE; THELLIER, 2013). Although the trial-anderror method can generate satisfactory results, optimization is likely to provide the best solutions, based on selected objectives. For this reason, Simulation-based Optimization (SBO) can be a process to achieve better-performing building designs (DELGARM et al., 2016).

SBO has been applied since the 1980 s on an international scale. However, due to the implementation of parametric modelling, since the 2010s, considerable research on SBO for building energy consumption has been developed. These researches aim to understand the most relevant building parameters and architectural configurations to promote energy efficiency (DELGARM et al., 2016).

We are optimizing means to minimize or maximize a function by systematically choosing values or real variables within a viable set. Moreover, optimization allows for exploring a large number of design solutions efficiently. However, building optimization involves a large number of variables, non-linear equations, and long simulation time (LARTIGUE; LASTERNAS; LOFTNESS, 2014).

The optimization process usually requires two types of inputs: variables and objective functions. In building performance optimization, variables are the values that control the geometry or any property related to design. The objective functions are the building performance metrics calculated by any simulation tools (MACHAIRAS; TSANGRASSOULIS; AXARLI, 2014).

An optimization problem can be mono or multicriteria, depending on the number of objective functions. Nguyen, Reiter, and Rigo (2014) identified that the first alternative is the most common, corresponding to $60 \%$ of the published scientific researches. However, MCDO is more likely to approach real problems since it deals with conflicting design criteria using two or more objectives to address essential limitations found in mono-objective problems (DELGARM et al., 2016).

Octopus ${ }^{\circledR}$ is an attractive plugin for working with MCDO. It allows the user to run mono or multi-objective optimization and has a diversify parameters option built-in, which increases the search field for solutions. Apart from determining the population size for each generation, it enables the user to set a maximum number of generations before the optimization process. The engine also prevents the optimization from being interrupted when faced with impossible cases and skips to the next solution when it reaches a maximum running time (FONSECA et al., 2017).

\section{Transitional spaces}

Transitional zones are the in-between architectural spaces, where the indoor and the outdoor climate meet and are modified without mechanical control. In these spaces, the occupants experience the weather change (CHUN; KWOK; TAMURA, 2004). They can also be used to alter occupants' expectations for environmental conditions when moving around a building.

The comfort conditions in transitional spaces are dynamic, unstable, and fluctuating. They are associated with many variables, such as solar radiation, temperature, and wind. In transitional spaces, the transient conditions are a consequence of the outdoors (PITTS, 2013). 
Transitional zones can be halls, canopies, lift lobbies, corridors, and staircases (Figure 1). According to Chun, Kwok, and Tamura (2004), and Pitts (2013), they are distributed into six broad types:

(a) Sheltered space, connected to the building, in which outdoor conditions predominate. They can be a balcony, a porch, a corridor or a covered street;

(b) Entrance areas with strong connections to the exterior, such as a hotel lobby or an atrium with continuously mixed conditions.

(c) Area set into the middle portion of an extended façade of a rectangular building. An atria zone or a courtyard;

(d) External perimeter corridor around the outside of the building;

(e) Semi-occupied space in which occupants gather for an extended time, which is not attached to a building and is virtually an outdoor room. The outdoor climate entirely influences it. Pergolas, bus stations or pavilions;

(f) Space parallel to the long axis of the building, such as a circulation zone or a corridor.

Figure 1 - Types of Transitional Spaces

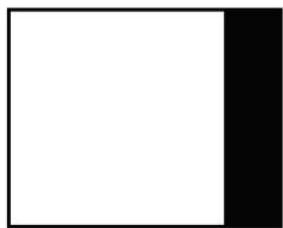

(a) Circulation Zone balcony

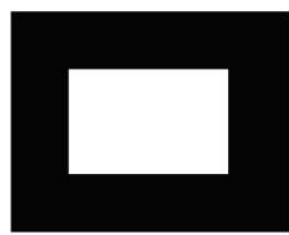

(d) Circulation Zone corridor

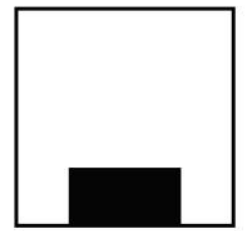

(b) Entrance Zone foyer/lobby

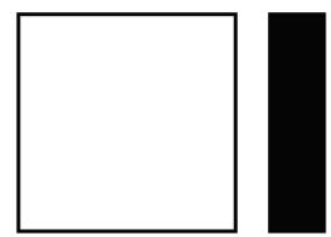

(e) Outdoor Zone porch

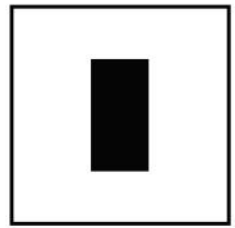

(c) Atria Zone courtyard

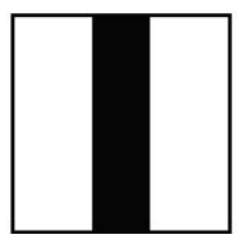

(f) Circulation Zone corridor

Source: Chun, Kwok, and Tamura (2004), and Pitts (2013), edited by the author.

\section{Assessment indices for transitional spaces}

Useful Daylight Illuminance (UDI) preserves much of the interpretive simplicity of the common daylight factor (DF) approach. It helps to interpret climate-based analyses of illuminance found on weather files. UDI employs realistic, time-varying sky and sun conditions, predicting levels of absolute daylight illuminance per hour in each point of the space. In contrast, the conventional DF provides a single number for each point in space (CARTANA, 2018; NABIL; MARDALJEVIC, 2006).

UDI is a dynamic measurement, mainly used for evaluation of admission and distribution of daylight. It establishes a lower limit of $100 \mathrm{Ix}$ and a higher limit of $2000 \mathrm{Ix}$ for the Daylight Admission (DA) (REINHART; MARDALJEVIC; ROGERS, 2006). It is expressed as a percentage of time per year in which daylight levels are within the desired range for the occupied hours.

Physiological Equivalent Temperature (PET) is another index that can be applied for transitional spaces. It is based on the Munich Energy-balance Model for Individuals (MEMI), which regards individuals' energy balance. PET is an index for calculating 
thermal comfort adapted to outdoor conditions, using the equation of human thermal equilibrium in a state of uniformity (MATZARAKIS; MAYER, 1996). Its values are estimated in degrees Celsius. PET is equivalent to the air temperature required to reproduce the core and skin temperatures for a standardized person in a standardized space. This person has a working metabolism of $80 \mathrm{~W}$ of light activity and $0.9 \mathrm{clo}$ of heat resistance (GUIMARÃES, 2016).

One of the advantages of PET is that the climate variables are the same as those used in other comfort indexes, enabling comparative analyses. Similar to Fanger's Predicted Mean Vote (PMV), PET uses the climatic variables: air temperature, relative humidity, air velocity, and mean radiant temperature to estimate the thermal sensation.

\section{Method}

This research is an exploratory approach, with experimental development (GROAT; WANG, 2013), inserted in the topic of BPS, with SBO for daylight, thermal performance, and comfort.

We organized the method according to the following steps, based on Cartana (2018) and Fang (2017):

(a) Shape optimization considering the exclusion of non-robust parameters dismissed through factorial analysis in previous work (LUCARELLI; CARLO, 2020);

(b) computational simulations on the admission of solar radiation and daylight performance in transitional spaces;

(c) comparative evaluation of the best solutions generated in the simulation process.

\section{Optimization}

Using Rhino3D+Grasshopper ${ }^{\circledast}$ parametric suite, we developed a script for an Origamishaped Canopy as a shading device element.

For the sake of optimization, we adopted Octopus ${ }^{\circledR}$ because it enables the user to work with MCDO and the diversify parameters option, which increases the chances of algorithm exploration in the entire search field of solutions. Octopus ${ }^{\circledR}$ also allows using two evolutionary algorithms: HypE and SPEA2. In this study, we used the evolutionary algorithm HypE because of its capacity to deal with multiple criteria.

The optimization objectives are the maximization of Average UDI and maximization of PET Percentage Time Comfortable (PTC). Average UDI is the sum of each UDI divided by the number of analysis points. Therefore, the maximization of the whole simulation grid should maximize each evaluation point.

PTC was used since we cannot maximize or minimize PET values as they range from -3.5 to 3.5 (Table 1). Therefore, we chose to maximize Percentage Time Comfortable (PTC), one of the outputs of Honeybee ${ }^{\circledR}$ Thermal Comfort Indices, which approximates PET to 0.0 (comfortable or neutral). The table also presents the correspondence of PET bands by variations of the PMV, on the seven-point scale.

This research focuses on the canopy performance because of its higher sensitivity to solar radiation admission and heat gain in lower latitudes. Besides, canopies are more susceptible to the visual discomfort caused by excessive intake of daylighting if treated as semi-permeable structures. 


\begin{tabular}{|c|c|c|}
\hline PMV & PET & Thermal Sensitivity \\
\hline-3.5 & $4^{\circ} \mathrm{C}$ & Very Cold \\
\hline-2.5 & $8^{\circ} \mathrm{C}$ & Cold \\
\hline-1.5 & $14^{\circ} \mathrm{C}$ & Cool \\
\hline-0.5 & $18^{\circ} \mathrm{C}$ & Slightly Cool \\
\hline 0.5 & $23^{\circ} \mathrm{C}$ & Comtortable (Neutral) \\
\hline 1.5 & $29^{\circ} \mathrm{C}$ & Warm \\
\hline 2.5 & $35^{\circ} \mathrm{C}$ & Hot \\
\hline 3.5 & $41^{\circ} \mathrm{C}$ & Very Hot \\
\hline
\end{tabular}

Source: Adapted from Matzarakis and Mayer (1996)

We started Octopus ${ }^{\circledast}$ with a population size of 30 and Max generations of 30 , based on previous investigations that combined simulation software, the required output, and the number of parameters (LUCARELLI; CARLO, 2020). During the simulation, we adopted the convergence of solutions as a stopping criterion.

We conducted the study for the city of Viçosa, MG, Brazil (Latitude $20^{\circ} 45^{\prime} 14^{\prime \prime} \mathrm{S}$, Longitude $42^{\circ} 52^{\prime} 55^{\prime \prime} \mathrm{W}$, Altitude $648 \mathrm{~m}$ ) with a TMY3 Weather File (GUIMARÃES, 2016). Since the canopy was created using a parametric modelling script, the SBO can occur anywhere, depending only on the weather file.

\section{Optimization objectives}

In Honeybee ${ }^{\circledR}$, the analysis grid for UDI is the same as the daylight sensors for annual simulation. The grid height was placed $0.1 \mathrm{~m}$ below the canopy. The distance between nodes was $1.5 \mathrm{~m}$, generating 9 points (Figure 2). To avoid interference from daylight that would not go through the canopy, we created an offset of $0.2 \mathrm{~m}$ from the outer border.

Figure 2 - UDI plane of analysis

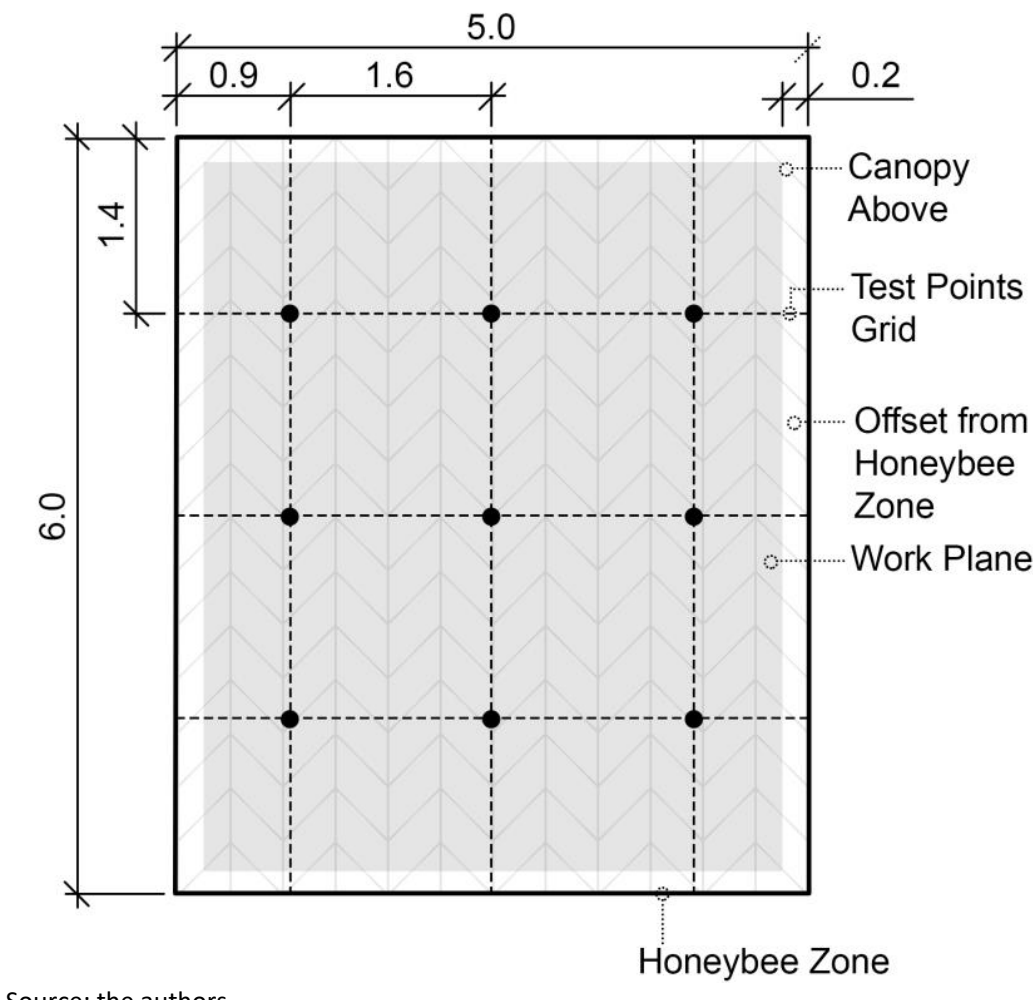

Source: the authors. 
For the PET analysis, the software interprets the whole space and generates one value. The assessment plan position in Grasshopper ${ }^{\circledR}$ was the same as the UDI analysis grid, considering an identical offset from the Honeybee ${ }^{\circledR}$ Zone.

Concerning the climate aspect, we adopted the PET input for Tropical and Subtropical Humid Climates according to the classification of Köppen-Geiger for Viçosa.

\section{Simulation}

Using Honeybee ${ }^{\circledast}$, we performed BPS on the admission of solar radiation and daylight. In all simulations, we positioned the solar shading device on a tiltable roof area (Figure 3).

Figure 3 - Optimization Parameters applied on Canopy

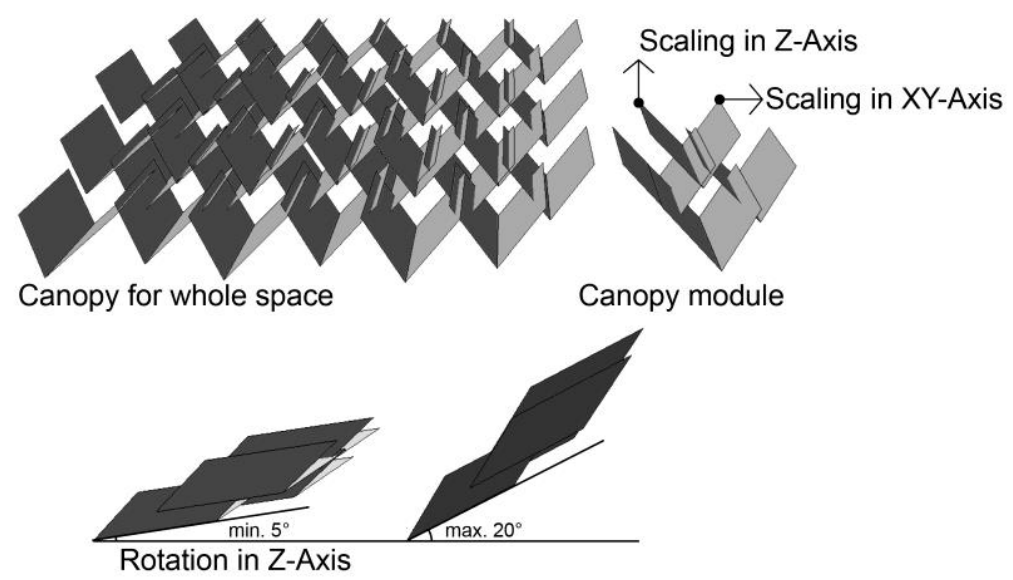

Source: the authors.

\section{Zones}

Chun, Kwok, and Tamura (2004) and Pitts (2013) discuss six different transitional spaces but highlight only three of them. In this research, we settled to work with these three options: Circulation, Entrance, and Atrium Zones (Figure 4).

Figure 4 - Transitional spaces chosen

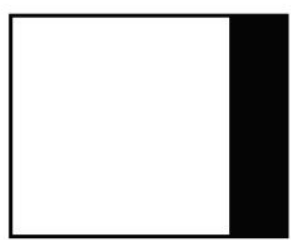

(a) Circulation Zone balcony

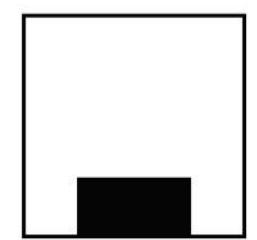

(b) Entrance Zone foyer/lobby

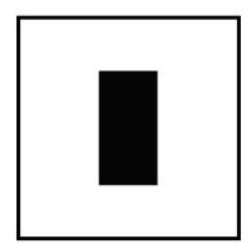

(c) Atria Zone courtyard

Source: the authors.

We conducted three main simulations. The first, represented by (a), did not have front or side context, which is a geometry that could block sunlight on the test geometry. In this first situation, the canopy attaches to a wall. We simulated PET only, since UDI requires an indoor space, averting the results from the proposed situation.

Metabolic rate is likely to be of slower walking pace or standing, occasionally higher or lower (Table 2). Clothing insulation is closer to outdoor measures. 
Table 2 - Simulation Parameters for each space

\begin{tabular}{cccc}
\hline Zone & $\begin{array}{c}\text { Metabolic rate } \\
\text { (met) }\end{array}$ & $\begin{array}{c}\text { Clothing insulation } \\
\text { (clo) }\end{array}$ & $\begin{array}{c}\text { Time of residence } \\
\text { (min) }\end{array}$ \\
\hline (a) & $1.2-1.7$ & $0.5-2.0$ & $5-15$ \\
\hline (b) & $1.7-2.0$ & $0.5-2.0$ & 5 \\
\hline (c) & $1.7-2.0$ & $0.5-1.0$ & $5-20$ \\
\hline
\end{tabular}

Source: the authors.

For the second condition, the canopy attaches to three walls. The simulation space is within a building, such as a hotel lobby, where conditions change as people move in and out. For this option, we simulated PET and UDI. We created a Honeybee ${ }^{\circledR}$ zone below the canopy for UDI simulation. We treat the openings as super clear glass and allow natural ventilation for both simulations.

The third condition operates similarly. The simulation space is also within a building with context geometries on four sides. For this option, we simulated PET and UDI.

For both, the metabolic rate is likely to be at walking pace level or above, depending on speed movement (Table 2). Clothing insulation varies. For the Entrance Zone, clothing insulation is closer to external measures or higher. For the Atria Zone, we worked with indoor standards. The period of residence for the second condition is likely to be short. For Atria Zones, time may vary according to the activity.

As Honeybee ${ }^{\circledast}$ simulation parameters, the wall and floor reflectance rates were $50 \%$ and $20 \%$, respectively. The material for the solar control element was a gray-diffuse metal, with a reflectance of $50 \%$ and emissivity of 0.04 . The occupancy time was from 6 am to $6 \mathrm{pm}$.

For daylight admission simulations, we used average UDI between 100lx and 2000lx, which corresponds to the summation of UDI percentages divided by the number of analysis points.

We performed simulations for all sunshine hours for one year.

\section{Results and Discussion}

\section{First condition - circulation zone}

For the first condition, PTC is the only optimization objective, which configures a monoobjective optimization. We activate the diversify parameters toggle to add another objective to the process, which creates an MCDO.

Running the optimization with the diversify parameters changed the range of solutions and created slight differences in the convergence and diversity maintenance behavior. When running the SBO without the diversify parameters, the convergence occurred on the seventeenth generation. With the option selected, the convergence happened on the twelfth (Figure 5).

As observed in Generation oo, all parameters are scattered throughout the graph. As the optimization advances, the lines move closer together. A smaller overlap indicates that the combination of parameters and variables are not as expressive as the variation of other parameters. 


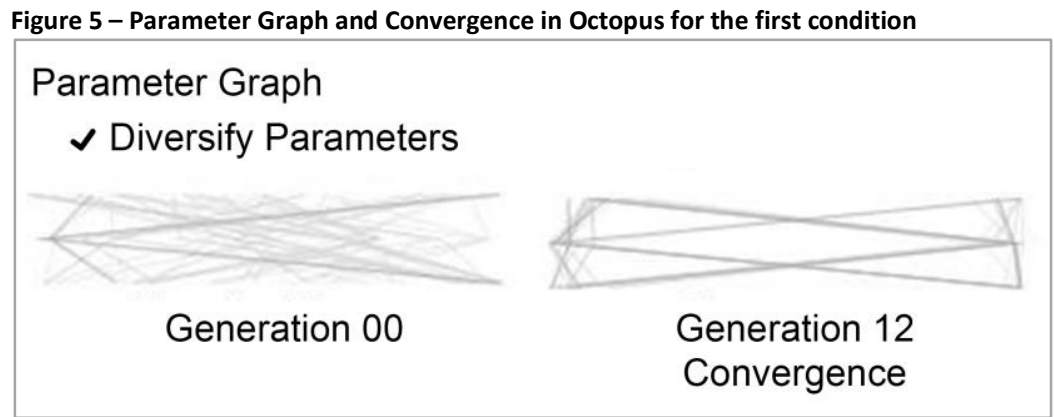

Source: the authors.

In Generation 12, the parameter scaling in XY-Axis, which performs the module opening, is the most expressive. It has the greatest effect on optimization. Opening in Z-axis is the least impactful.

Although both parameters apply to module opening, XY-Axis scaling was more expressive because it affects the number of hours a day the canopy admits daylight inside the transitional space. Z-Axis concerns a vertical opening, with less impact on the number of daylight hours.

Concerning optimization objectives, maximizing the PTC caused PET to approach o, which means a neutral thermal sensitivity.

For the first condition, the relation between PTC and Diversify Parameters (Figure 6) shows the progression of the results towards $100 \%$ PTC. The adoption of the diversify parameters' option enabled different geometries with the same PET levels, which means more results with the same computational time. The wide variety of results indicates the importance of decision making in determining a final solution. There is a range of results that achieved the maximum PTC of 93,75\%, which indicates that other issues must be addressed to select the best of them.

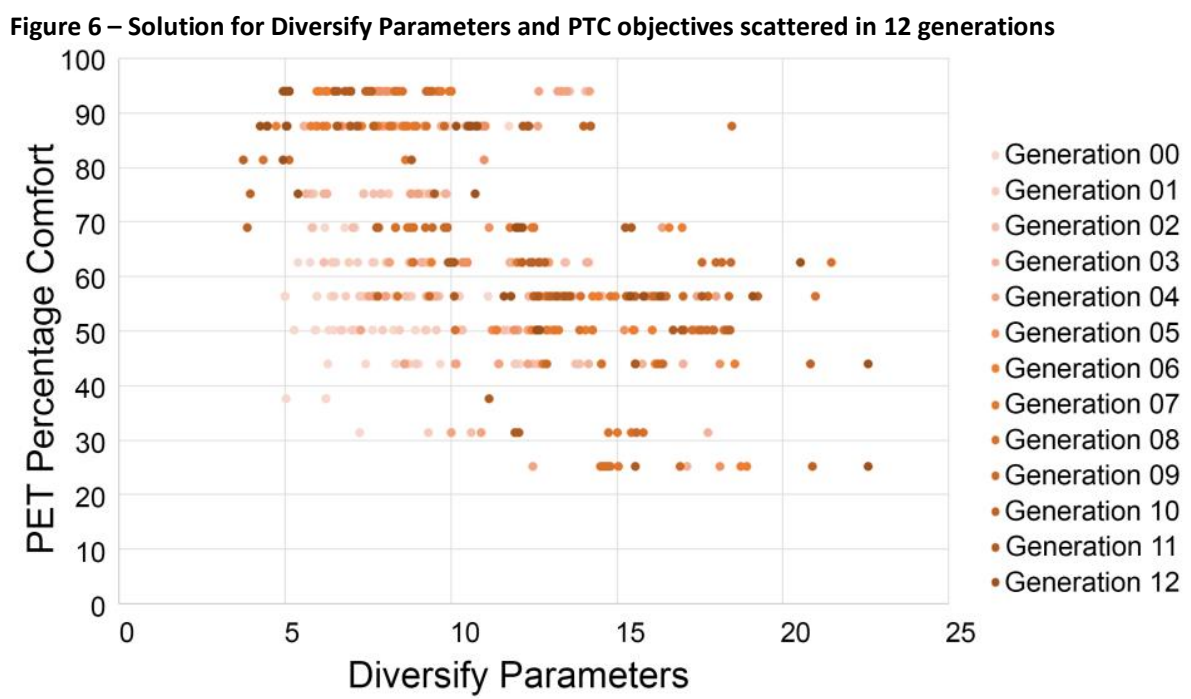

Source: the authors.

The base case represents a simulation for the selected transitional space, with the context geometry and no canopy. This context geometry, as addressed before, is the building in which the canopy attaches. It could block sunlight in the transitional space but does not affect the canopy in this base case. In this circumstance, PTC returned results of $0 \%$ with a PET of 3.5 , indicating a very hot thermal sensitivity. 


\section{Second condition - entrance zone}

For the second condition, we used UDI and PTC as optimization objectives. We also worked with the diversify parameters option to create a comparison between this condition and the first. Octopus maximized both UDI and PTC, and the convergence occurred on the twelfth generation (Figure 7).

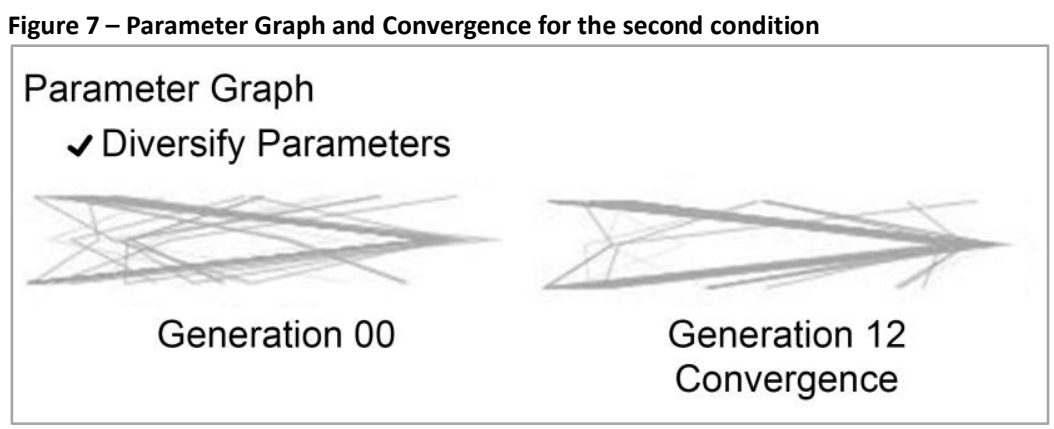

Source: the authors.

Unlike the first condition, in the PTC versus Diversify Parameters graph, the PTC presents more scattered results (Figure 8), and despite reaching a lower maximum, it has a higher minimum. Still, the diversify parameters provided a variety of results with the same PET level.

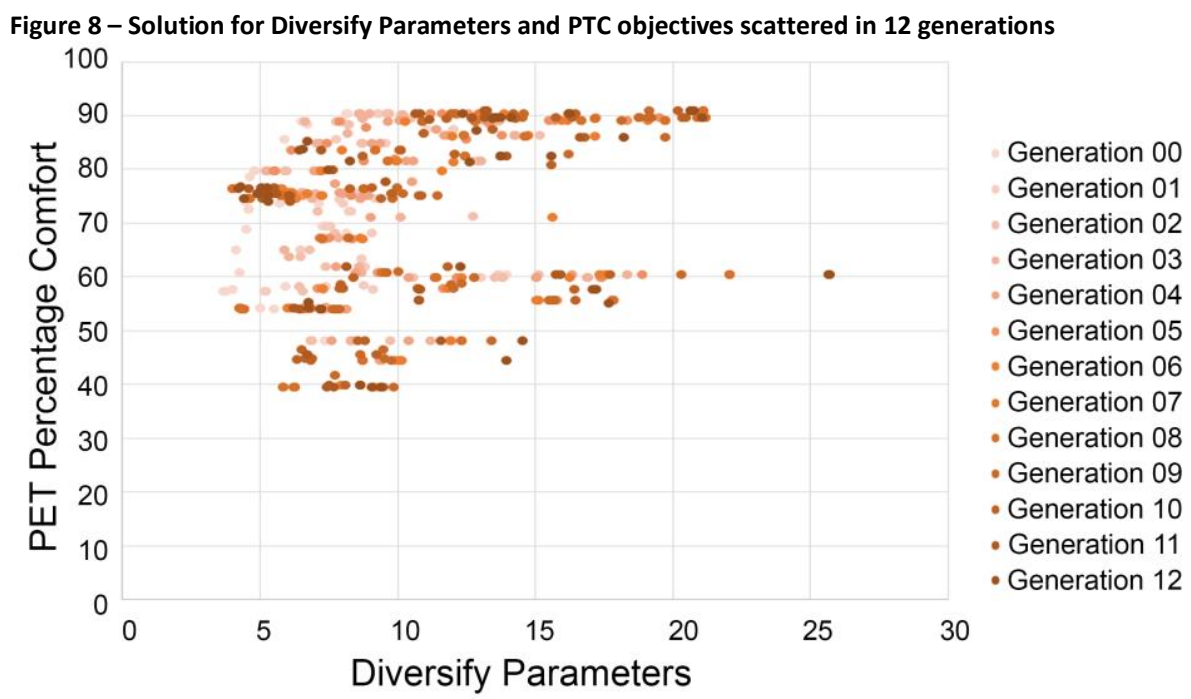

Source: the authors.

Concerning UDI and PTC dispersion (Figure 9), the higher the illuminance, the lower the thermal sensitivity, tending to results higher than 0.0 for PET since sunlight is composed of the visible light spectrum, infrared and ultraviolet energy. Infrared energy is an example of thermal radiation and, therefore, a mechanism of heat transfer.

As the generations progress, UDI and PTC advance on the Pareto Frontier. Higher values of UDI result in lower levels of PET due to the admission of heat. An optimal selection should consider a balance between light admission and thermal sensitivity. For this reason, we select as an optimal design a point in the Pareto Front knee, which approaches the Utopia Point ${ }^{1}$. 


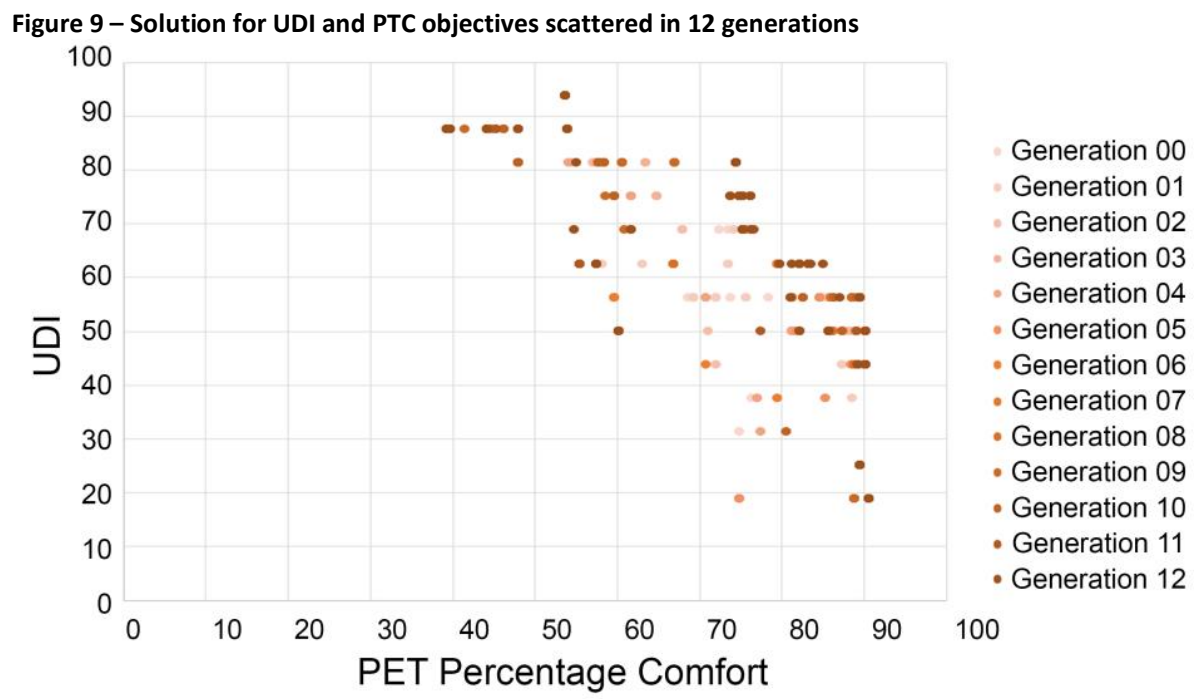

Source: the authors.

In general, the three last generations compose the Pareto frontier, which indicates conversion. In MCDO, all points on the Pareto front are potentially an optimal solution. If we are to analyze the best solutions for the canopy, knowing that UDI and PET are conflicting objectives, we can choose extreme cases in which either UDI or PTC are maximum.

The first extreme case would represent a maximum UDI of $93.8 \%$, with a minimum PTC of $53.8 \%$.

Thus, for $93.8 \%$ of the occupied hours in a year, daylight levels are within the range of $100-2000 \mathrm{Ix}$, and in $53.8 \%$ of the time, thermal sensitivity is within the comfort range.

The second extreme case consists of a PTC of $90.7 \%$ and an UDI of $18.8 \%$. In this case, daylight levels are within $100-2000 \mathrm{~lx} 18.8 \%$ of the simulated hours.

An intermediate case that would approach the Utopia point has an UDI of $62.5 \%$ and a PTC of $85.1 \%$. It is a balance between UDI and PTC, with $62.5 \%$ of the occupied hours within daylight levels of $100-2000$ Ix and $85.1 \%$ of comfort hours.

Similar to the first simulation, the base case has a context geometry but no canopy. The context geometry for the Entrance Zone provides more shading and presents a maximum PTC of $11.2 \%$, with an UDI of $5 \%$.

From 8760 simulated hours, the intermediate case accounts for 5475 hours with daylight levels between 100-2000 Ix, while the base case has 438 . For PTC, the intermediate case offers 7455 hours in comfort, while the base case presents 981.

Third condition - atria zone

The third condition is similar to the second. We maximized UDI and PTC using the diversify parameters' toggle, and the convergence appeared on the thirteenth generation (Figure 10).

When running the MCDO without the diversify parameters' option, the convergence occurred on the seventeenth generation, which provided less optimal results with more computational time.

In this SBO, the analysis of the dispersion of Diversify Parameters and PTC presented more concentrated results (Figure 11). The maximum PTC is the lowest of all three conditions due to thermal sensitivity for cold. The minimum PTC is the highest of all 
three simulations since the context geometry, even without canopy, prevents intense radiation and reaches higher PTC values.

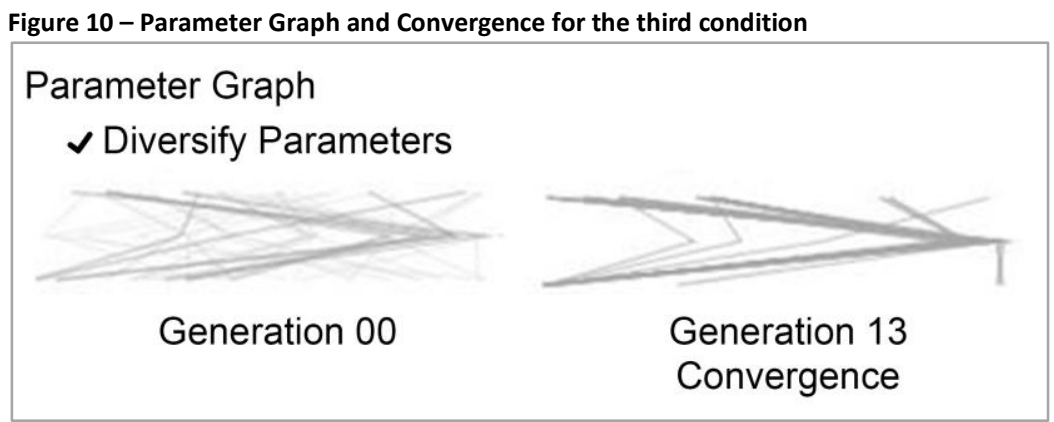

Source: the authors.

Figure 11 - Solution for Diversify Parameters and PTC objectives scattered in 13 generations

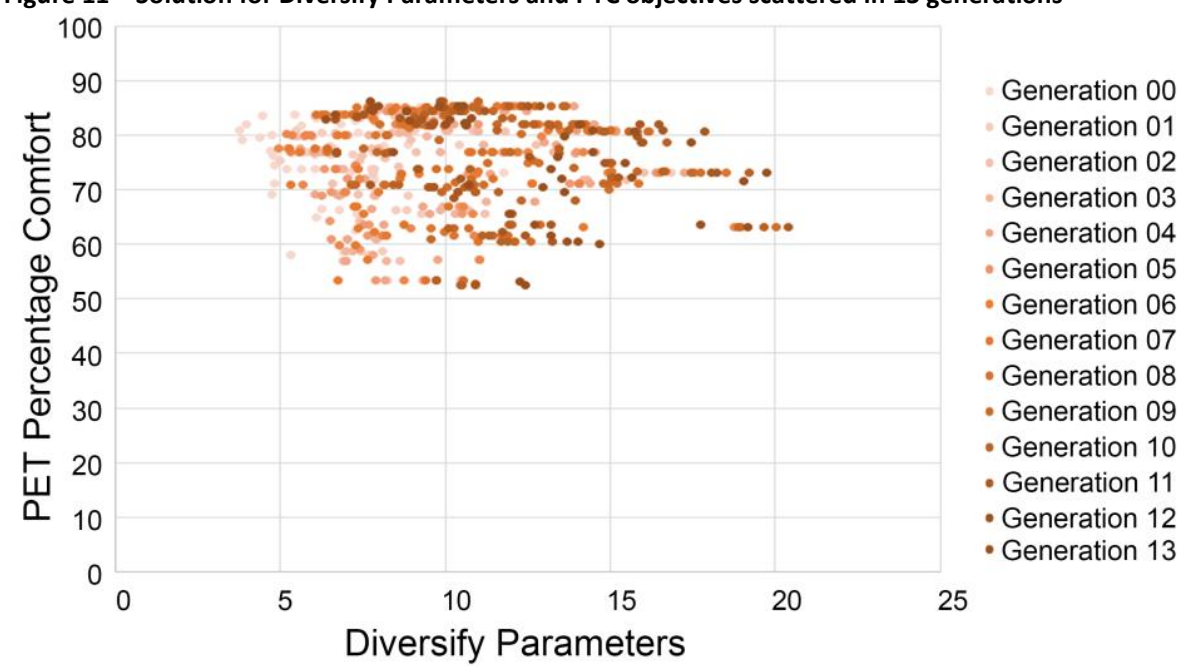

Source: the authors.

The analysis of the PTC and UDI dispersion (Figure 12) revealed that the context geometry also caused PTC to reach higher values than the other conditions, due to its higher minimums.

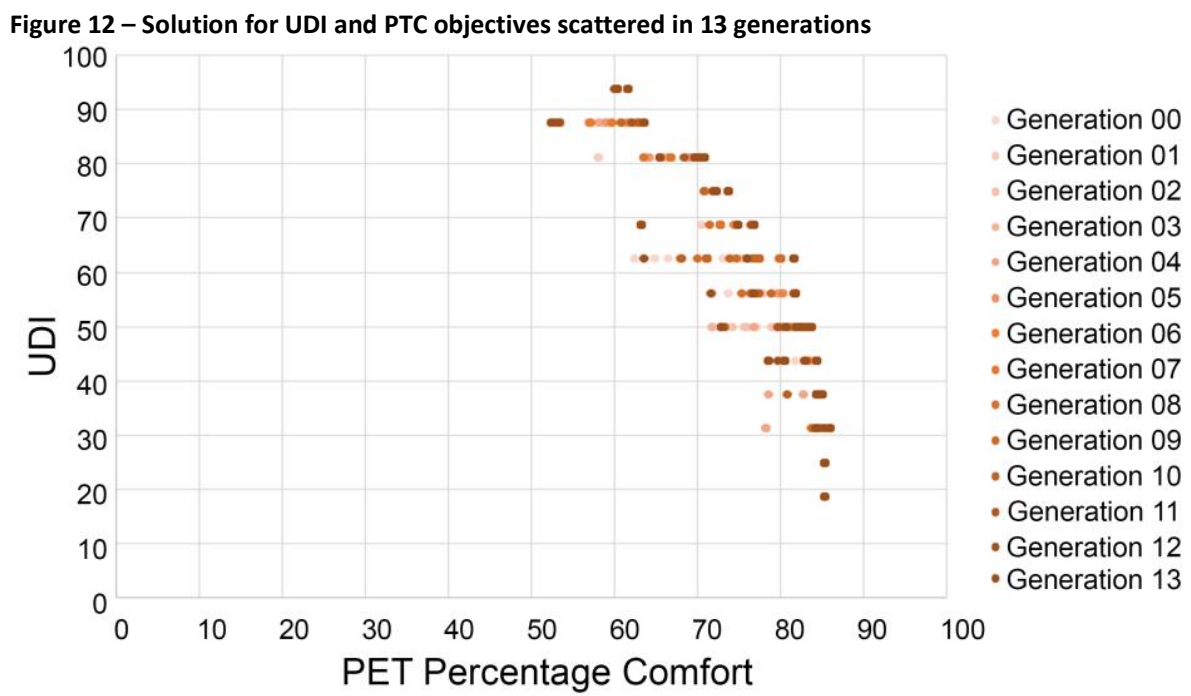

Source: the authors. 
UDI values are slightly lower than those in the Entrance Zone, which is coherent. The illuminance infiltrating the space derives from the canopy openings, and the context geometry blocks any other gains. In the Entrance Zone, the illuminance level also considers daylight coming from the front, where there is no context geometry. The last generations contain the best results and still form the Pareto front.

If we follow the same selection criteria for the Second condition, we can pick extreme cases and an intermediate result.

For the first extreme case, Pareto maximum UDI reached 93.8\%, which indicates that, in $93.8 \%$ of the occupied hours, illuminance levels are within the range of 100-2000 Ix. PTC is $61.7 \%$, which shows that $61.7 \%$ of the simulated time, thermal sensitivity is within the neutral range.

The other extreme situation returned a PTC of $86.1 \%$ with an UDI of $18.8 \%$. In this case, we achieve thermal comfort of $86.1 \%$ of the simulated hours. The illuminance levels are within the accepted range, only in $18.8 \%$ of the cases.

The intermediate solution, closer to the Utopia point, presents an UDI of $62.5 \%$ and PTC of $82.7 \%$. The PET value is close to the second extreme situation, with a high PTC, if associated with ASHRAE 55's $80 \%$ adaptive comfort acceptance rate.

The base case has the context geometry, the surrounding Atria Zone, with no canopy test geometry. Even without the canopy, the context provides shading and presents a maximum PTC of $14.2 \%$ and UDI of $13 \%$. These results present the transitional spaces as passive strategies for shading and thermal comfort.

Out of the 8760 simulated hours, the intermediate case accounts for 5475 hours, with daylight levels between 100-2000 Ix, while the base case has 1139. For PTC, the intermediate case offers 7245 hours in comfort, while the base case presents 1244 .

In Figure 13, we show all the selected cases with the optimization parameter percent. For the first SBO, we have one expressive parameter, which is the PTC. The diversify parameters option changes accordingly, enabling other design possibilities. Changes in the design are subtle, but, as discussed in previous research (LUCARELLI; CARLO, 2020), we worked with robust optimization parameters that greatly impacted thermal sensitivity and daylight.

These changes in the design may affect structure rigidity, material consumption, water runoff, and other parameters not included in the SBO. These parameters can help with the decision-making process. For example, when facing optimization results that returned the same PTC or UDI values, water runoff and constructability could be decisive.

When examining the variations in the second and third conditions, the changes in design are more apparent. UDI meddles with the optimization process by raising XY-Axis values to collect more daylight and increase illuminance values.

The more daylight inserted in the space, the higher the radiation values and thermal sensitivity. Consequently, PTC and UDI are conflicting optimization objectives.

To achieve higher thermal comfort percent, PTC manipulates Scaling in Z-Axis and XYAxis, thus increasing the first and diminishing values for the second. In the second and third conditions, the MCDO for UDI and PTC showed XY-Axis values of $0 \%$ while trying to maximize the opening in Z-Axis. 


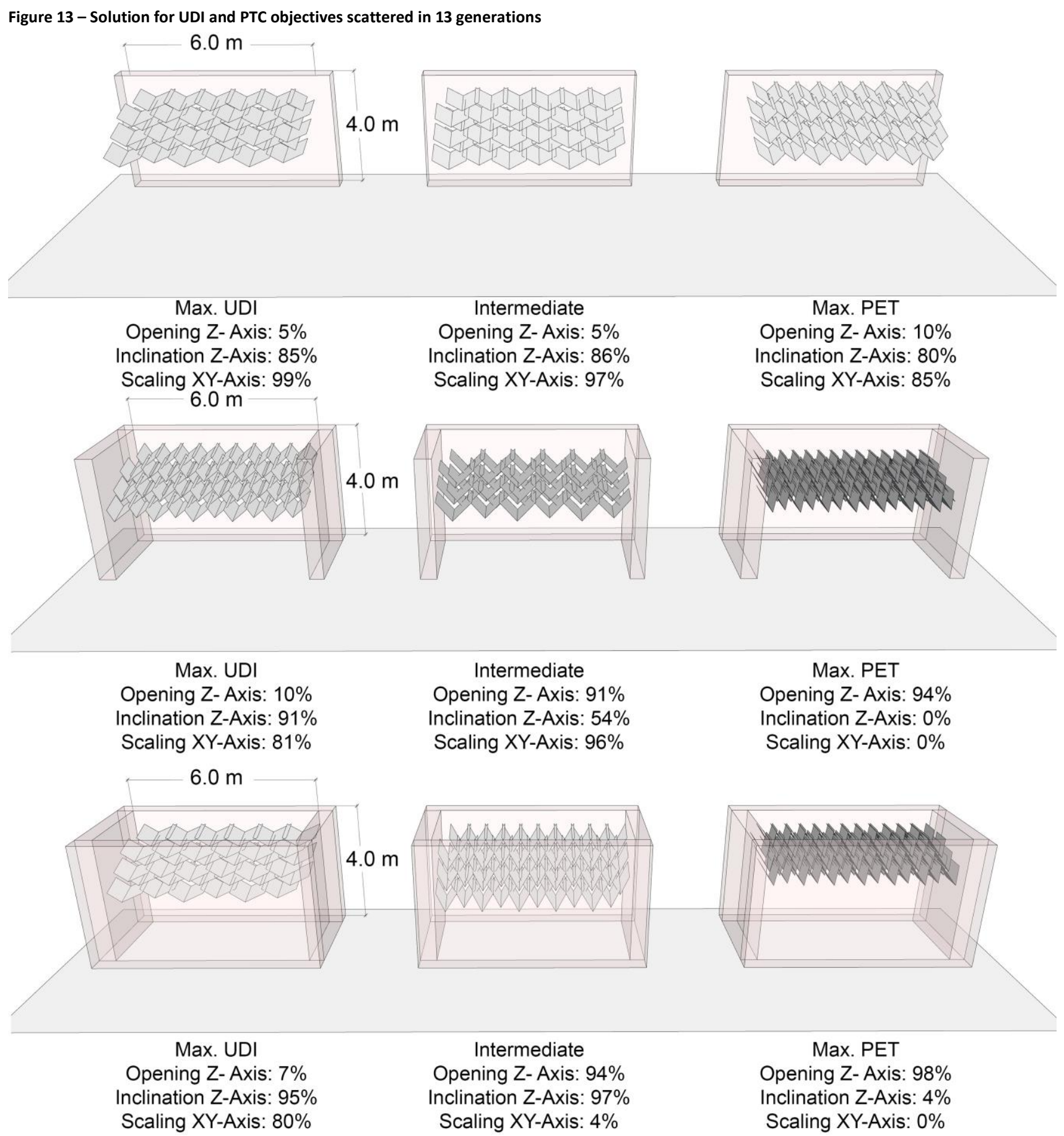

Source: the authors.

\section{Conclusions}

This paper presents exploratory research on the potential application of SBO tools to an Origami-inspired canopy. We investigate parameters, such as module size and opening, to satisfy the optimization Indices for Transitional Spaces, employing digital simulation tools for quantitative daylighting expressed by the UDI. We combined them in an MCDO with radiation analysis for PTC to identify an optimum canopy design.

The paper also presented a literature review on all topics uncovered through the study. We discussed energy consumption and performance, computational simulations, 
parametric simulation, SBO, and evolutionary algorithms. We also introduced notions of transitional spaces.

The primary purpose of this study was to simulate and optimize a complex parametric geometry based on Origami shapes. It was applied in a semi-outdoor space where neither indoor nor outdoor assessment indices would apply.

Among the main conclusions, we can highlight that the optimization objectives were conflicting. The higher the PTC values, the lower the UDI, due to the infrared heat transfer. The higher the illuminance levels permitted, the higher the infrared energy and radiation levels.

Optimization results returned a Pareto Frontier that illustrates this logic. The optimization process dealt only with quantitative objectives, thus making the designer responsible for applying qualitative objectives. Generally, the Utopia point in a Pareto Frontier shows the best optimization results for both objectives. However, knowing that maximizing daylight would offset PET values from the thermal comfort sensitivity, we chose to analyze the Utopia point and extreme cases.

Another important conclusion concerns the use of the diversify parameters option, not implemented in the cited literature. For all zones, the diversify parameters increased the quality of results in a distinctive way. For Circulation Zones, it was necessary to configure an MCDO. It sped the parameter convergence and provided more optimal results. For Entrance and Atria Zones, it also helped to speed the optimization process delivering better results.

In an MCDO, there is no final optimal result. For the three cases, the three selections can configure an optimal geometry, depending on the objective envisioned. If we are to answer to the optimization objectives set in Octopus, we could say that the results near the Utopia point are the optimal solutions.

Selecting Utopia points, for Circulation Zones, the maximization of PTC reached $93.75 \%$ of simulated hours in thermal comfort. Since PTC was the only optimization objective inserted in Octopus for this condition, each $93.75 \%$ point in the graph represents a different geometry, which gives the designer the option to choose between slightly different canopy configurations.

For the Entrance Zone Utopia point, PTC was $85.1 \%$, and UDI was $62.5 \%$, which means that in $85.1 \%$ of the simulated time, the user is in thermal comfort and $62.5 \%$ of the time, the illuminance levels in the simulated space are between 100 and $2000 \mathrm{Ix}$. In the Pareto Front analysis for the second condition, the maximum PTC is $90.7 \%$, and the maximum UDI is $93.8 \%$. PTC is lower in the second condition due to the context geometry that affects radiation levels in the canopy.

For the Atria Zone, the results were similar to the second condition, although PTC was consistently higher, with a lower maximum. For the Utopia point, PTC was $82.7 \%$, and UDI, 62.5\%, which means that despite the decreased radiation levels, illuminance levels were maintained. This condition may have resulted from reflected radiation inlet, which reduces infrared radiation and internal heat gains. For this zone, the maximum UDI was 93.8\%, and the maximum PTC was $86.1 \%$. Once more, PTC is lower than the previous condition, due to additional context geometry that acts as shading.

\section{Acknowledgements}

We are thankful to Fundação de Amparo à Pesquisa do Estado de Minas Gerais (FAPEMIG) for the scholarship granted (5273/15). 


\section{Notas}

(1) A Utopia solution does not usually exist, but the Utopia point is an ideal standard in a Pareto optimal set. In the plot, the Utopia point has coordinates that simultaneously maximize both criteria, occupying the edge of the criterion space.

\section{References}

ANDJELKOVIC, A. S.; MUJAN, I.; DAKIC, S. Experimental validation of an EnergyPlus model: Application of a multistory naturally ventilated double skin façade. Energy and Buildings, v. 118, p. 27-36, 2016. DOI:https://doi.org/10.1016/j.enbuild.2016.02.045

CAMPOS, F. M. D. Estudo do uso de parametrização e simulações computacionais nas etapas iniciais do processo de projeto visando à otimização. 2017. 191 f. Dissertação (Mestrado em Arquitetura e Urbanismo) —Faculdade de Engenharia Civil, Arquitetura e Urbanismo, Universidade Estadual de Campinas, Campinas. 2017. Disponível em: http://repositorio.unicamp.br/handle/REPOSIP/322276. Acesso em: 01 de setembro de 2019

CARTANA, R. P. Desempenho térmico e lumínico de elementos de controle solar para fachadas desenvolvidos com modelagem paramétrica e fabricação digital. 2018. Tese (Doutorado em Arquitetura e Urbanismo) -

Departamento de Arquitetura e Urbanismo, Universidade Federal de Santa Catarina, Florianópolis. 2018. Disponível em: https://repositorio.ufsc.br/handle/123456789/193318. Acesso em: 03 Setembro de 2019

CHO, J.; YOO, C.; KIM, Y. Viability of exterior shading devices for high-rise residential buildings: Case study for cooling energy saving and economic feasibility analysis. Energy and Buildings, v. 82, p. 771-785, 2014. DOI:https://doi.org/10.1016/j.enbuild.2014.07.092

CHUN, C.; KWOK, A.; TAMURA, A. Thermal comfort in transitional spaces - basic concepts: literature review and trial measurement. Building and Environment, v. 39, p. 1187-1192, 2004.

DOI:https://doi.org/10.1016/j.buildenv.2004.02.003

DELGARM, N.; SAJADI, B.; KOWSARY, F.; DELGARM, S. Multi-objective optimization of the building energy performance: A simulation-based approach by means of particle swarm optimization (PSO). Applied Energy, v. 170, p. 293-303, 2016. DOI:https://doi.org/10.1016/j.apenergy.2016.02.141

ELTAWEEL, A.; SU, Y. Parametric design and daylighting: A literature review. Renewable and Sustainable Energy Reviews, v. 73, p. 1086-1103, 2017. DOI:https://doi.org/10.1016/j.rser.2017.02.011

FANG, Y. Optimization of Daylighting and Energy Performance Using Parametric Design, Simulation Modeling, and Genetic Algorithms. 2017. 123 f. Tese (Doutorado em Design)_Graduate Faculty of North Carolina, North Caroline State University, Raleigh. 2017. Disponível em: https://repository.lib.ncsu.edu/handle/1840.20/33696. Acesso em: 01 setembro de 2019

FONSECA, L. P. G.; NUNES, V. D. L.; SANTANA, L. O.; CARLO, J. C.; CÉSAR JÚNIOR, K. M. L. Otimização multiobjetivo das dimensões dos ambientes de uma residência unifamiliar baseada em simulação energética e estrutural. Ambiente Construído, v. 17, n. 1, p. 267-288, 2017. DOI:https://doi.org/10.1590/s1678-86212017000100135

FRAZER, J. Parametric Computation: History and Future. Architectural Design, v. 86, p. 18-23, 2016. DOI:https://doi.org/10.1002/ad.2019

GARBER, R. Optimisation Stories: The Impact of Building Information Modelling on Contemporary Design Practice. Architectural Design, v. 79, n. 2, p. 6-13, 2009. DOI:https://doi.org/10.1002/ad.842

GOSSARD, D.; LARTIGUE, B.; THELLIER, F. Multi-objective optimization of a building envelope for thermal performance using genetic algorithms and artificial neural network. Energy and Buildings, v. 67, p. $253-260,2013$. DOI:https://doi.org/10.1016/j.enbuild.2013.08.026 
GROBMAN, Y.; CAPELUTO, G.; AUSTERN, G. External shading in buildings: comparative analysis of daylighting performance in static and kinetic operation scenarios. Architectural Science Review, v. 60, n. 2, p. 126-136, 2017. DOI:https://doi.org/10.1080/00038628.2016.1266991

GUIMARÃES, Í. Análises de Incertezas e Sensibilidade de Arquivos Climáticos e seus impactos em simulações computacionais termo energéticas. 2016. 95 f. Dissertação (Mestrado em Arquitetura e Urbanismo) Departamento de Arquitetura e Urbanismo, Universidade Federal de Viçosa, Viçosa. 2016. Disponível em: https://www.locus.ufv.br/handle/123456789/20623. Acesso em 28 de outubro de 2019

KIRIMTAT, A.; KREJCAR, O.; EKICI, B.; TASGETIREN, M. Multi-objective energy and daylight optimization of amorphous shading devices in buildings. Solar Energy, v. 185, p. 100-111, 2019.

DOI:https://doi.org/10.1016/j.solener.2019.04.048

KO, Y. Urban Form and Residential Energy Use. Journal of Planning Literature, v. 28, n. 4, p. 327-351, 2013. DOI:https://doi.org/10.1177/0885412213491499

KOLAREVIC, B.; MALKAWI, A. Performative Architecture: Beyond Instrumentality. Nova York: Spoon Press, 2006. v. 60. DOI:https://doi.org/10.1111/j.1531-314x.2006.00068_1.X

LARTIGUE, B.; LASTERNAS, B.; LOFTNESS, V. Multi-objective optimization of building envelope for energy consumption and daylight. Indoor and Built Environment, v. 23, n. 1, p. 70-80, 2014.

DOI:https://doi.org/10.1177/1420326X13480224

LOPES, F.; CÓSTOLA, D.; LABAKI, L. Simulação De Estratégias Bioclimáticas Passivas Para Edifício De Escritórios Em Clima Tropical Semiúmido. In: XIV Encontro Nacional de Conforto no Ambiente Construído, 2017, Balneário Camboriú. Anais [... ]. Balneário Camboriú: ENCAC, 2017, p. 1-11. Disponível em: https://www.researchgate.net/publication/323524962_SIMULACAO_DE_ESTRATEGIAS_BIOCLIMATICAS_PASSIVAS PARA_EDIFICIO_DE_ESCRITORIOS_EM_CLIMA_TROPICAL_SEMIUMIDO. Acesso em: 27 de outubro de 2019

LUCARELLI, C. D. C.; CARLO, J. C. Parametric Modeling Simulation for an origami shaped canopy. Frontiers of Architectural Research, v. 9, n. 1, p. 67-81, 2020. DOI:https://doi.org/10.1016/j.foar.2019.08.001

MACHAIRAS, V.; TSANGRASSOULIS, A.; AXARLI, K. Algorithms for optimization of building design: A review. Renewable and Sustainable Energy Reviews, v. 31, p. 101-112, 2014. DOI:https://doi.org/10.1016/j.rser.2013.11.036

MATEUS, N.; PINTO, A.; GRAÇA, G. da. Validation of EnergyPlus thermal simulation of a double skin naturally and mechanically ventilated test cell. Energy and Buildings, v. 75, p. 511-522, 2014.

DOI:https://doi.org/10.1016/j.enbuild.2014.02.043

MATZARAKIS, A.; MAYER, H. Another kind of environmental stress: Thermal stress. Who Newsletter, v. 18, p. 7-10, 1996. Disponível em:

https://www.researchgate.net/publication/233759000_Another_kind_of_environmental_stress_Thermal_stress. Acesso em: 15 de outubro de 2019

NABIL, A.; MARDALEVIC, J. Useful daylight illuminance: A replacement for daylight factors. Energy and Buildings, v. 38, n. 7, p. 905-913, 2006. DOI:https://doi.org/10.1016/j.enbuild.2006.03.013

NGUYEN, A.; REITER, S.; RIGO, P. A review on simulation-based optimization methods applied to building performance analysis. Applied Energy, v. 113, p. 1043-1058, 2014. DOI:https://doi.org/10.1016/j.apenergy.2013.08.061

OCHOA, C.; ARIES, M.; HENSEN, J. State of the Art in Lighting Simulation for Building Science: A Literature Review. Journal of Building Performance Simulation, p. 37-41, 2012. DOI:https://doi.org/10.1080/19401493.2011.558211

OXMAN, R. Theory and design in the first digital age. Design Studies, v. 27, n. 3, p. 229-265, 2006.

DOI:https://doi.org/10.1016/j.destud.2005.11.002 
PENG, Y.; FENG, T.; TIMMERMANS, H. A path analysis of outdoor comfort in urban public spaces. Building and Environment, v. 148, n. August 2018, p. 459-467, 2019. DOI:https://doi.org/10.1016/j.buildenv.2018.11.023

PEREIRA, E. B.; MARTINS, F. R.; GONÇALVES, A.; COSTA, R.; LIMA. F.; RÜTHER, R.; DE ABREU, S.; TIEPOLO, G. PEREIRA, S.; DE SOUZA, J. 2017. Atlas Brasileiro de Energia Solar (2 ${ }^{a}$ edição). São José dos Campos: Inpe. Disponível em: https://www.researchgate.net/publication/319305620 Atlas Brasileiro de Energia Solar - 2 Edicao/citations. Acesso em: 18 de outubro de 2019

PITTS, A. Thermal Comfort in Transition Spaces. Buildings, v. 3, n. 1, p. 122-142, 2013. DOI:https://doi.org/10.3390/buildings3010122

REINHART, C.; MARDALJEVIC, J.; ROGERS, Z. Dynamic Daylight Performance Metrics for Sustainable Building Design. The journal of the illuminating Engineering Society of North America, v. 3, n. 1, p. 7-31, 2006.

DOI:https://doi.org/10.1582/LEUKOS.2006.03.01.001

ROUDSARI, M.; PAK, M. Ladybug: A parametric environmental plugin for grasshopper to help designers create an environmentally-conscious design. In: 13TH Conference of International Building Performance Simulation Association, 2013, França. Anais [... ]. França: IBPSA, 2013, p. 3128-3135. Disponível em:

https://www.researchgate.net/publication/287778694_Ladybug_A_parametric_environmental_plugin_for_grassho pper to help_designers_create_an_environmentally-conscious_design. Acesso em: 18 de outubro de 2019

WONG, I. A review of daylighting design and implementation in buildings. Renewable and Sustainable Energy Reviews, v. 74, n. February, p. 959-968, 2017. DOI:https://doi.org/10.1016/j.rser.2017.03.061

YIGIT, S.; OZORHON, B. A simulation-based optimization method for designing energy efficient buildings. Energy and Buildings, v. 178, p. 216-227, 2018. DOI:https://doi.org/10.1016/j.enbuild.2018.08.045

YU, X.; SU, Y. Daylight availability assessment and its potential energy saving estimation -A literature review. Renewable and Sustainable Energy Reviews, v. 52, p. 494-503, 2015. DOI:https://doi.org/10.1016/j.rser.2015.07.142

ZHOU, J.; MOHD NAZI, W.; WANG, Y.; ROSKILLY, A. Investigating the impact of building's facade on the building's energy performance - A case study. Energy Procedia, v. 158, p. 3144-3151, 2019.

DOI:https://doi.org/10.1016/j.egypro.2019.01.1016

\section{${ }^{1}$ Caio de Carvalho Lucarelli}

Arquiteto e Urbanista. Mestre em Arquitetura e Urbanismo. Doutorando no Programa de Pós Graduação de Arquitetura e Urbanismo da Universidade Federal de Viçosa. Endereço postal: Av. P. H. Rolfs, s/nº, Centro, Viçosa, Minas Gerais, Brasil, 36570-900

\section{Joyce Correna Carlo}

Arquiteta e Urbanista. Doutora em Engenharia Civil. Professora do Departamento de Arquitetura e Urbanismo da Universidade Federal de Viçosa e professora e coordenadora na pós-graduação em Arquitetura e Urbanismo na mesma instituição (PGAU/UFV). Endereço postal: Av. P. H. Rolfs, s/nº, Centro, Viçosa, Minas Gerais, Brasil, 36570-900

\section{Andressa Carmo Pena Martinez}

Arquiteta e Urbanista. Doutora em Urbanismo. Professora do Departamento de Arquitetura e Urbanismo da Universidade Federal de Viçosa e professora na pós-graduação em Arquitetura e Urbanismo na mesma instituição (PGAU/UFV). Endereço postal: Av. P. H. Rolfs, s/nº, Centro, Viçosa, Minas Gerais, Brasil, 36570-900 